\title{
PEMANFAATAN TEKNOLOGI TEPAT GUNA DALAM MENINGKATKAN PRODUKSI RENGGINANG DI KELURAHAN SIDODADI KOTA SAMARINDA
}

\author{
Netty Maria Naibaho ${ }^{1}$, Andi Lisnawati ${ }^{2}$, Khusnul Khotimah ${ }^{3}$, Rudito ${ }^{4}$, Anis \\ Syauqi ${ }^{5}$, Mujibu Rahman ${ }^{6}$, Tere Adi Susanti ${ }^{7}$, Hamka $^{8}$, M. Yamin ${ }^{9}$ \\ ${ }^{1}$ Politeknik Pertanian Negeri Samarinda \\ email: maria_nethy@yahoo.com \\ ${ }^{2}$ Politeknik Pertanian Negeri Samarinda \\ email: alis_manis75@yahoo.com \\ ${ }^{3}$ Politeknik Pertanian Negeri Samarinda \\ email: khusnul_khotimah@yahoo.com \\ ${ }^{4}$ Politeknik Pertanian Negeri Samarinda \\ email: ruditoasmoro@yahoo.co.id \\ ${ }^{5}$ Politeknik Pertanian Negeri Samarinda \\ email: annisyauqi@yahoo.co.id \\ ${ }^{6}$ Politeknik Pertanian Negeri Samarinda \\ email: mujiburahman2002@yahoo.co.id \\ ${ }^{7}$ Politeknik Pertanian Negeri Samarinda \\ email: tere_susanti@gmail.com \\ ${ }^{8}$ Politeknik Pertanian Negeri Samarinda \\ email: hamkanurkaya@gmail.com \\ ${ }^{9}$ Politeknik Pertanian Negeri Samarinda \\ email: yaminpoliagro@gmail.com
}

\begin{abstract}
Rengginang is one of Indonesia's traditional foods that is widely consumed as a snack. Rengginang is generally made from leftover rice. Rengginang processing is very simple including drying and frying. Because the taste is tasty and crispy Rengginang become one of the products that has a business opportunity for the community. It has a positive effect for partners and other Rengginang entrepreneurs about the importance of using simple appropriate technology, so as to be able to improve the Rengginang production process. The introduction and provision of packaging equipment (sealers) are also very important to maintain the quality of the rengginang produced. This activity also accompanied the Rengginang industry players to obtain a legal permit number of small industry to ensure food safety for consumers. Science and Technology activities for the community are expected to continue as an effort to provide guidance and assistance to micro businesses so they can survive and develop in the future.
\end{abstract}

Keywords: rengginang; printer; oven; packer; $P$-IRT

\section{ABSTRAK}

Rengginang adalah salah satu makanan tradisional Indonesia yang banyak dikonsumsi sebagai camilan. Umumnya Rengginang dibuat dari sisa nasi yang tidak habis. Pengolahan Rengginang sangat sederhana termasuk pengeringan dan penggorengan. Karena rasanya yang gurih dan renyah Rengginang menjadi salah 
satu produk yang memiliki peluang bisnis bagi masyarakat. Hal Ini memiliki efek positif bagi mitra dan pengusaha Rengginang lainnya tentang pentingnya menggunakan teknologi tepat guna yang sederhana, sehingga dapat meningkatkan proses produksi Rengginang. Pengenalan dan penyediaan peralatan pengemasan (sealer) juga sangat penting untuk menjaga kualitas rengginang yang diproduksi. Kegiatan ini juga mendampingi pelaku industri Rengginang untuk mendapatkan nomor izin industri kecil yang sah untuk memastikan keamanan pangan bagi konsumen. Kegiatan IPTEK bagi masyarakat diharapkan berlanjut sebagai upaya memberikan bimbingan dan bantuan kepada usaha mikro sehingga mereka dapat bertahan dan berkembang di masa depan.

Kata Kunci: rengginang; alat pencetak; pengering; pengemasan, P-IRT

\section{PENDAHULUAN}

Sejak dahulu kala rengginang sudah dikenal sebagai makanan tradisional khas nusantara. Rengginang pada awalnya dibuat dari sisa nasi yang tidak habis, daripada terbuang sia-sia makanan tersebut dikeringkan lalu digoreng sehingga menjadi sejenis kerupuk. Makanan yang gurih dan renyah ini sudah menjelma dengan berbagai resep dan variasi dan tentunya tidak hanya mengandalkan sisa nasi, namun dibuat dari beras ketan. Mitra merupakan salah satu pengusaha industri rumah tangga di kota Samarinda yang membuat rengginang. Usaha milik Mitra merupakan salah satu usaha kecil yang menggunakan bahan dasar beras ketan untuk menjadi rengginang dengan rasa asin, manis, terasi dan bawang. Apabila ada permintaan akan rengginang dalam jumlah yang banyak dan cepat, maka Mitra tidak mampu untuk memenuhinya. Hal ini disebabkan pengeringan masih memanfaatkan sinar matahari. Jika cuaca mendung, maka rengginang yang dihasilkan bu darmini akan lambat kering, dan kadang rengginang tersebut berjamur. Selain itu alat untuk mencetak rengginang juga sederhana dengan menggunakan pipa paralon. Begitu pula dengan pengemasan yang masih menggunakan kresek. Sehingga hanya mampu dijual dipasar tradisional, padahal jika dikemas dengan baik harga rengginang ini di tingkat pasar modern cukup bersaing artinya bisa lebih menguntungkan lagi. Kelemahan seperti proses pencetakan, proses pengeringan yang menggunakan sinar matahari serta serta tidak adanya tenaga kerja tambahan membuat produksi rengginang ini tidak bisa banyak dan tidak stabil. Satu hari atau dalam dua hari Mitra hanya bisa memproduksi rengginang sekitar $25 \mathrm{~kg}$ saja itupun jika cuaca panas tetapi jika cuaca hujan Mitra tidak dapat memproduksi. Jika produksi tetap dipaksakan dapat menimbulkan kerugian karena bahan yang sudah diolah akan mudah rusak jika tidak langsung dikeringkan. Pengeringan rengginang paling tidak memakan waktu 8-10 jam dengan catatan kondisi cuaca panas sepanjang hari. Selain itu jika pengeringan tidak maksimal maka menyebabkan rengginang cepat rusak karena berjamur.

Untuk mengatasi masalah tersebut, maka perlu penggunaan alat-alat teknologi sederhana yang dapat membantu mempercepat proses pengolahan produk tersebut. Misalnya penggunaan alat pencetak, dan oven serta alat 
pengemasan sederhana. Dengan adanya penggunaan alat-alat teknologi tersebut maka Mitra bisa mengolah produksi setiap hari dan tidak tergantung cuaca. Begitupula dengan adanya alat pencetak proses pencetakan lebih cepat dan hasilnya rengginang yang diproduksi memiliki ukuran dan ketebalan yang seragam. Ditunjang dengan pengemasan yang baik maka produksi rengginang ini dapat menembus pasar modern. Dengan adanya bantuan alatalat tersebut selain kapasitas produksi bisa ditingkatkan kualitasnya semakin membaik dan rengginang ini memiliki daya simpan yang lama. Selain itu pengurusan P-IRT juga sangat penting dalam industri rumah tangga karena menjamin keamanan bahan pangan dipasaran.

\section{METODE PELAKSANAAN}

Berdasarkan hasil identifikasi maka ditemukan beberapa permasalahan yang perlu dicari solusi alternatifnya. Salah satu permasalahannya adalah produksi rengginang di Mitra yang selama ini masih menggunakan pencetakan manual yaitu memanfaatkan paralon sebagai cetakan, sehingga proses produksipun lambat. Hal lain yang juga menjadi masalah mitra adalah proses pengeringan. Mitra biasanya memanfaatkan sinar matahari untuk mengeringkan rengginang. Ketika hujan dan cuaca mendung mengakibatkan rengginang tidak dapat dijemur, sehingga bahan baku tersebut dapat rusak dan berjamur. Oleh karena itu diperlukan suatu alat yang berteknologi untuk mencetak dan mengeringkan rengginang dalam meningkatkan kualitas dan kuantitas produksi.

Pengemasan merupakan dasar permasalahan dalam pemasaran IRT mitra. Karena faktor penyebabnya mitra mengemas rengginang hanya menggunakan kantong plastik atau kardus, sehingga pemilikpun kurang percaya diri dalam memasarkan produknya. Padahal rengginang ini memiliki potensi memungkinkan yang dapat dipasarkan ke masyarakat luas dengan membuat kemasan yang cantik. Selama ini mitra tidak mengetahui apa itu PIRT sehingga rengginang yang diproduksipun tidak ada label P-IRTnya.

Berdasarkan kesepakatan Tim Pelaksana bersama Mitra, maka masalah yang harus diselesaikan adalah sebagai berikut:

1. Memberikan pengenalan teknologi tepat guna yang mudah diterapkan, yaitu mendesain alat pengering (oven) berbahan bakar api dan pencetak rengginang dari baja.

2. Membuat alat sesuai dengan desain yang ditentukan, dalam hal ini fokus pada alat untuk pengeringan dan pencetakan.

3. Melaksanakan demonstrasi alat pengering, pencetak, pengemas yang diberikan kepada mitra untuk memastikan kelayakan peralatan tersebut.

4. Melaksanakan pelatihan dan pendampingan penggunaan peralatan.

5. Meningkatkan kualitas rengginang dengan penggunaan pengemasan yang lebih baik akan menambah daya tarik pembeli, sehingga produk tidak hanya dijual kepasar tradisonal saja akan tetapi memasuki pasar modern.

6. Membantu pengurusan P-IRT dari Dinas Kesehatan 
Adapun lokasi pelaksanaan pengabdian masyarakat ini dilaksanakan dijalan KS. Tubun gang 9 RT 36 Samarinda dengan jarak dari kampus Politeknik Pertanian Negeri Samarinda kurang lebih 15 km, akses jalan baik dan lancar dengan waktu tempuh kurang dari 30 menit perjalanan. Target dari pengabdian masyarakat ini terdiri dari satu IRT Mitra. Kegiatan ini dilaksanakan dalam bentuk workshop pengolahan dan pengemasan rengginang disekitar usaha Mitra, dikarenakan sekitar $75 \%$ masyarakat tersebut berwirausaha rengginang. Diharapkan dengan program ini dapat berdampak kepada masyarakat disekitarnya.

Tim Pelaksana mengharapkan partisipasi peserta dengan (1) Bersedia berdiskusi dan berpartisipasi aktif dalam pelaksanaan program pelatihan dan pendampingan; (2) Ikut memberikan saran pada saat mendesain peralatan yang diperlukan; (3) Berpartisipasi dalam demonstrasi peralatan dengan menyiapkan sarana dan prasarana yang dimiliki mitra tempat demonstrasi; (4) Bersedia mengikuti pelatihan pembuatan P-IRT di dinas kesehatan; dan (5) Bersedia bekerjasama dengan tim pelaksana secara berkelanjutan.

\section{HASIL DAN PEMBAHASAN}

Ipteks bagi masyarakat ini kegiatan awal pertama yang dilakukan adalah proses survey pada usaha rengginang dan wawancara yang mendalam kepada pengusaha dan melihat secara langsung proses produksi pembuatan rengginang yang berada di KS Tubun Gg. 9 RT. 36 Kelurahan Sidodadi Jawa Kecamatan Samarinda llir, Kota Samarinda dengan jarak dari kampus Politeknik Pertanian Negeri Samarinda kurang lebih 15 km, akses jalan baik dan lancar dengan waktu tempuh kurang dari 30 menit perjalanan. Kemudian dilakukan analisis dengan tim kelompok Ipteks tentang usaha yang dijalankan oleh Mitra, permasalahan serta teknologi tepat guna yang bisa membantu kelancaran dan pengembangan usaha dikemudian hari, alat-alat yang dibutuhkan untuk membantu peningkatan proses produksi dan peningkatan kualitas mutu rengginang yang akan dihasilkan.

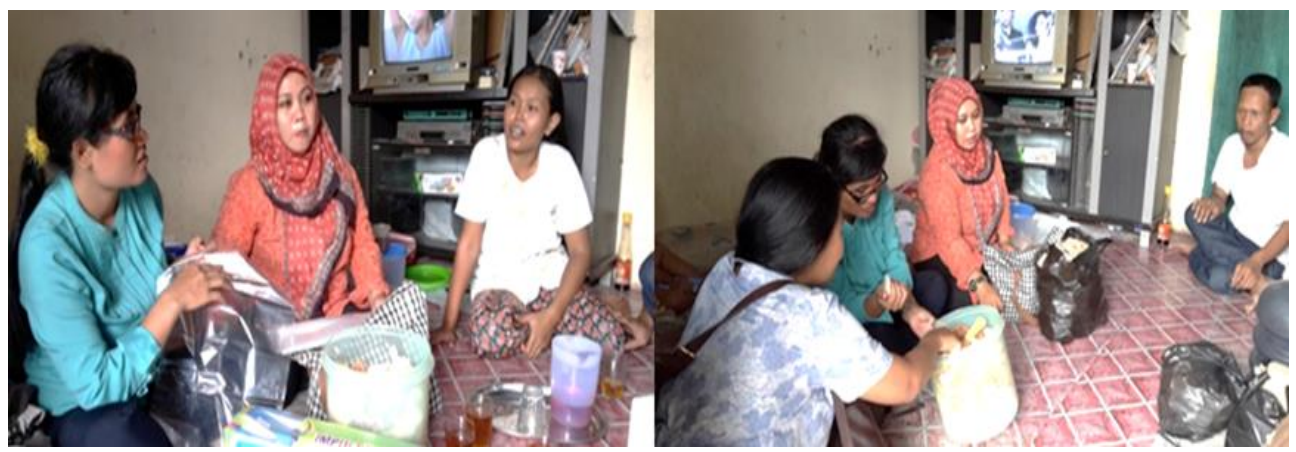

Gambar 1. Koordinasi ketempat Mitra 
Produksi rengginang milik Mitra hanya bisa memproduksi perhari sekitar $20-25 \mathrm{~kg}$ perhari atau $600-750 \mathrm{~kg}$ perbulan jika cuaca panas. Apabila cuaca tidak bersahabat atau sering hujan, maka produksi dikurangi, karena proses produksi yang masih menggunakan mengandalkan tenaga manusia. Selain itu, proses pengeringan pengeringan masih menggunakan cara konvensional yakni dengan menggunakan cahaya matahari. Matahari adalah sumber daya alam yang sangat berguna bagi manusia dan merupakan sumber energi yang murah karena tidak perlu membayar untuk mendapatkannya. Penjemuran biasanya dilakukan di tempat yang terbuka sehingga mendapatkan sinar matahari secara langsung. Saat cuaca mendung maka kualitas rengginang yang seharusnya sudah kering menjadi terhambat proses pengeringannya karena tidak ada matahari lagi. Ini tentu menimbulkan aroma tidak sedap pada rengginang karena terkena hujan atau pengeringan yang tidak sempurna dikarenakan kurangnya cahaya matahari. Kondisi ini menyebabkan usaha rengginang milik Mitra hanya mampu mensuplai rengginang sekitar $25-30 \%$ dari kebutuhan. Apabila ada kebutuhan rengginang dalam jumlah yang banyak dan mendesak, tidak dapat dipenuhi sesuai dengan permintaan karena keterbatasan dan kesederhanaan alat. Banyaknya permintaan akan rengginang ini karena rasanya yang khas yaitu bumbu rasa terasi, terasi, manis dan asin tidak seperti rengginang lainnya.

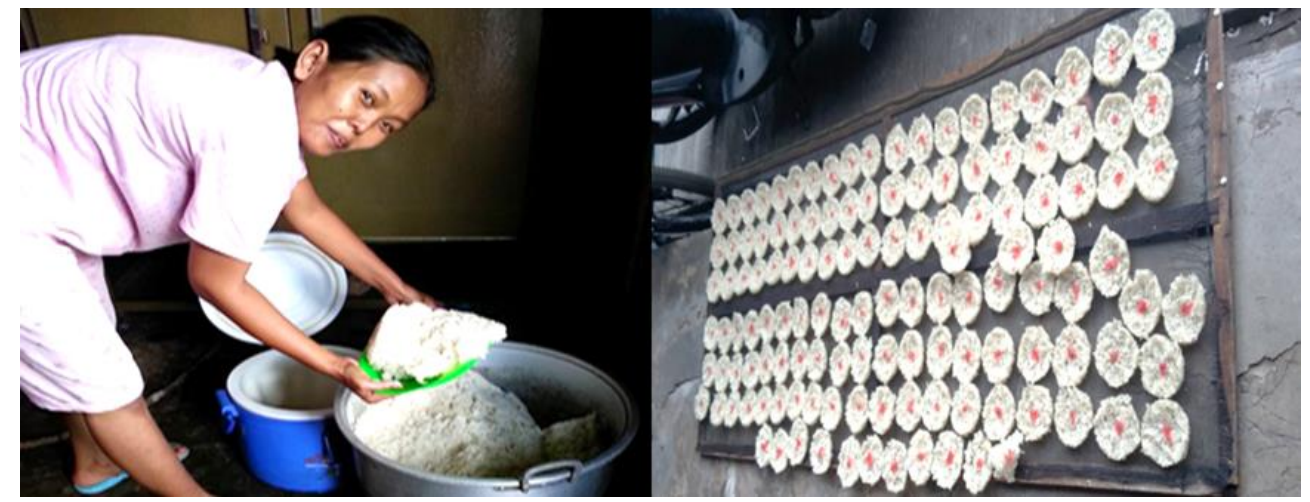

Gambar 2. Produksi rengginang

Peluang usaha ini bisa berkembang dengan baik, keberadaan industri kecil ini terhadap lingkungannya akan sangat berarti bagi masyarakat disekitar lokasi, karena lokasi produksi berada pada lokasi yang padat penduduk dan beberapa masyarakatnya juga membuat rengginang. Berkembangnya usaha kecil ini akan berdampak langsung dan sangat positif terhadap kehidupan masyarakat utamanya para ibu-ibu dan remaja disekitar tempat itu dan juga memberikan peluang untuk bekerja, magang, dan membuka usaha baru.

Permasalahan yang dihadapi oleh usaha rengginang milik Mitra adalah rendahnya kapasitas produksi dikarenakan alat yang dimiliki masih sederhana hanya mengandalkan pencetak dan pengering manual yang memakan waktu 
lama, tergantung pada kondisi cuaca serta kemasan yang masih sederhana dan mengandalkan plastik/kresek biasa tanpa label nama.

Metode pengeringannya hanya tergantung pada cuaca panas dan dijemur pada halaman rumah dan diatas atap rumah tetangga sehingga produk bisa terkontaminasi dengan bakteri atau kotoran. Kelemahan proses penjemuran kerupuk dengan cara konvensional ini saat proses penjemuran harus ada yang menunggu untuk mengangkat rengginang jika tiba-tiba terjadi hujan, terkadang ada banyak aktivitas lain selain harus menunggu rengginang. Ini tentu menambah pekerjaan dan merepotkan manusia. Oleh karena itu setelah melihat dan mempelajari kondisi permasalahan yang dihadapi oleh usaha rengginang milik Mitra, maka kami telah melakukan kegiatan yaitu:

1. Memberikan pengenalan teknologi tepat guna untuk membantu kelancaran dan peningkatan produksi rengginang yaitu berupa pencetak rengginang, sehingga mampu meningkatkan produksi dan kualitas rengginang. Biasanya Mitra hanya produksi rengginang sekitar 10-25 $\mathrm{kg} / \mathrm{dua}$ hari. Namun setalah mendapat bantuan cetakan rengginang, saat ini sudah mampu mencapai peningkatan produksi sekitar 30-50 $\mathrm{kg} /$ harinya.

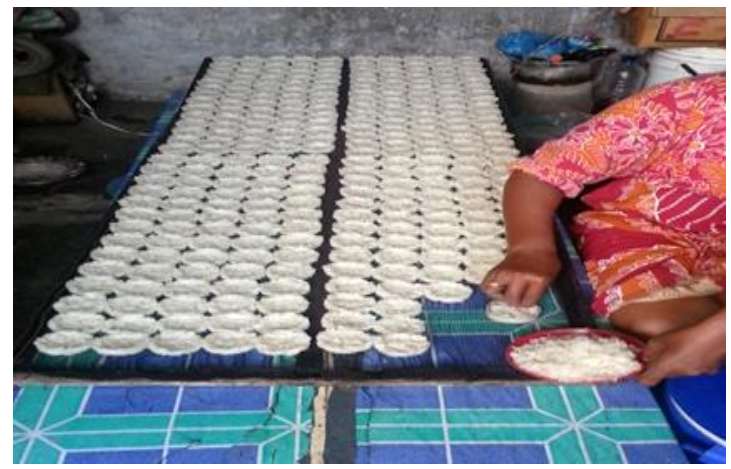

Gambar 3. Penggunaan paralon sebagai pencetak

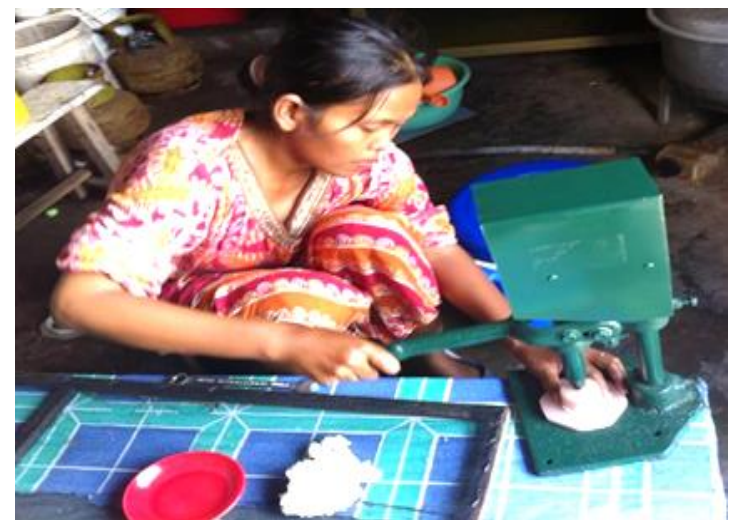

Gambar 4. Penggunaan alat bantuan 


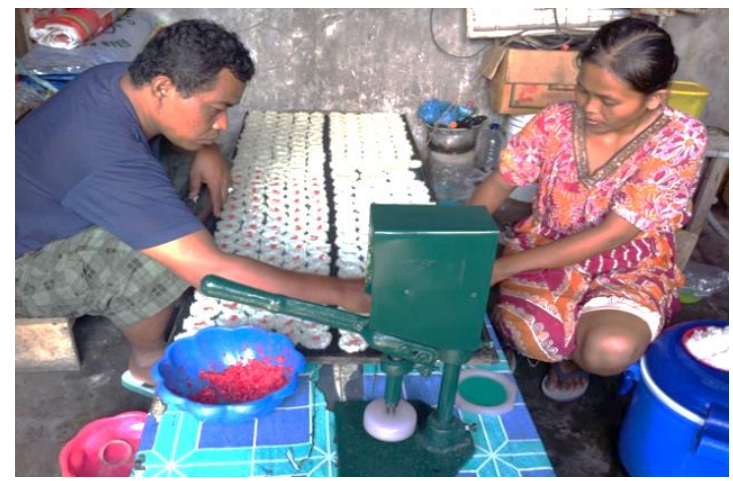

Gambar 5. Penggunaan alat bantuan

2. Memberikan pengenalan teknologi tepat guna untuk meningkatkan kualitas rengginang yaitu berupa pengering (oven) sebagai pengering, dengan adanya bantuan pengering ini, ibu Darimini sudah mampu memproduksi rengginang setiap harinya tanpa tergantung cuaca dan kondisi. Penggunaan alat (oven) teknologi tepat guna ini dapat mempercepat proses pengeringan rengginang, sehingga rengginang dapat kering dengan baik dan produk bisa bertahan lama serta bebas dari kontaminasi bakteri dan kotoran. Biasanya Mitra mengeringkan rengginang sekitar 8-10 jam dengan sinar matahari jika cuaca sangat terik. Setelah mendapat pengering ini, Mitra dapat mengeringkan rengginang 2-5 jam setiap harinya. Selain itu, masyarakat disekitar rumah Mitra juga memanfaatkan pengering (oven) ini untuk mengeringkan rengginang mereka, jika Mitra belum memakai alat pengering tersebut.

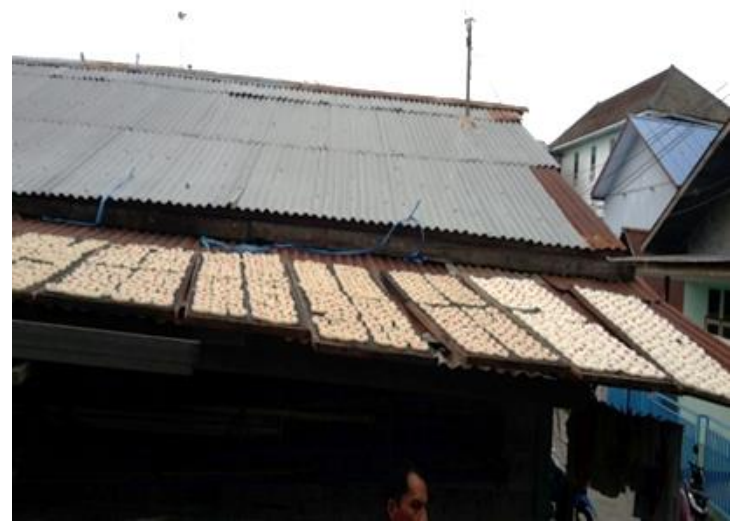

Gambar 6. Pengeringan memanfaatkan sinar matahari 


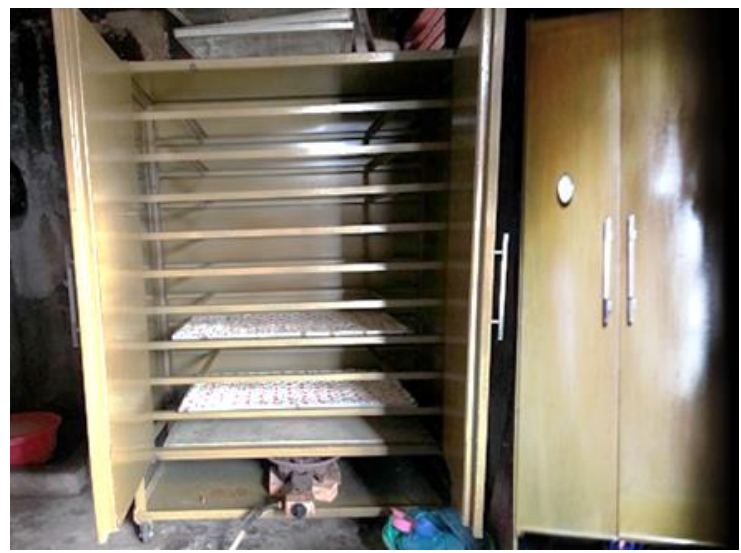

Gambar 7. Pengering dengan Oven

3. Memberikan pengemas plastik (sealer) untuk mempermudah pengemasan produk rengginang. Penggunaan sealer ini dapat mempertahankan karakteristik dari produk rengginang, tetap kering dan kualitas terjaga selama proses pemasaran sampai ketangan konsumen. Awalnya mitra menggunakan plastik/kresek biasa untuk mengemas rengginang, sehingga memungkinkan produk rengginang dapat melempem dan mudah terkontaminasi oleh bakteri maupun kotoran. Oleh karena itu, kami mencoba mengganti kemasan kresek menjadi kemasan plastik Polyetyhlen yang tebal yang dilengkapi dengan label kemasan yang menarik.

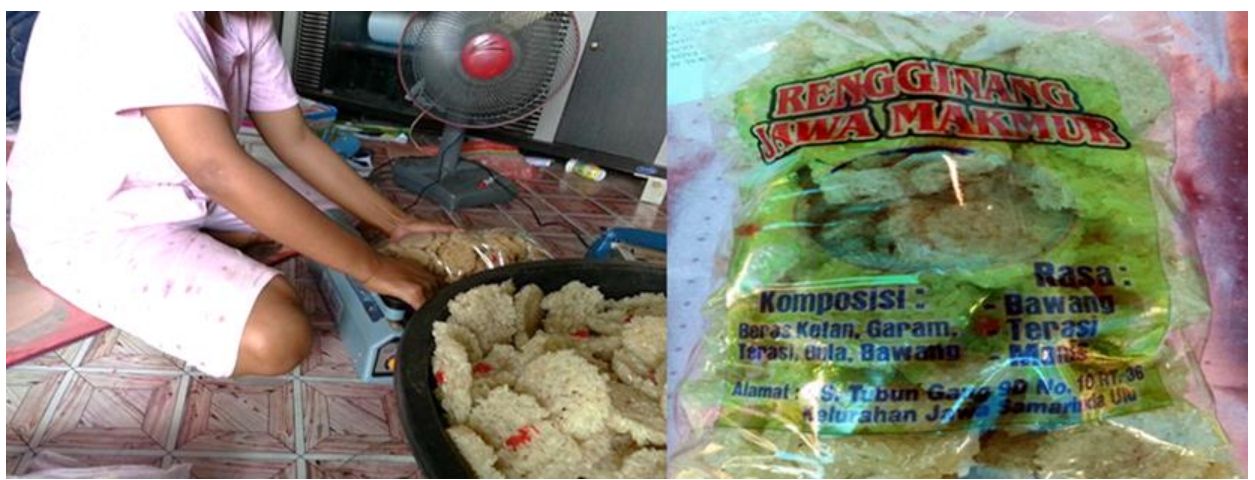

Gambar 8. Pengemasan dengan Sealer dan Kemasan plastik yang menarik lengkap dengan label

4. Memberikan bantuan kepada mitra dalam hal pengurusan P-IRT. Selain sebagai bentuk perlindungan terhadap konsumen, upaya ini dilakukan agar daya saing produk tersebut semakin meningkat. Pembuatan kode PIRT dilabel kemasan juga dapat meningkatkan kepercayaan daya beli konsumen terhadap rengginang karena proses pembuatannya sudah tersertifikasi dan terdaftar di dinas kesehatan kota Samarinda. Untuk 
mendapatkan P-IRT ini Mitra telah mengikuti pelatihan yang diadakan oleh Dinas Kesehatan Samarinda dan sudah mendapatkan kode P-IRT.

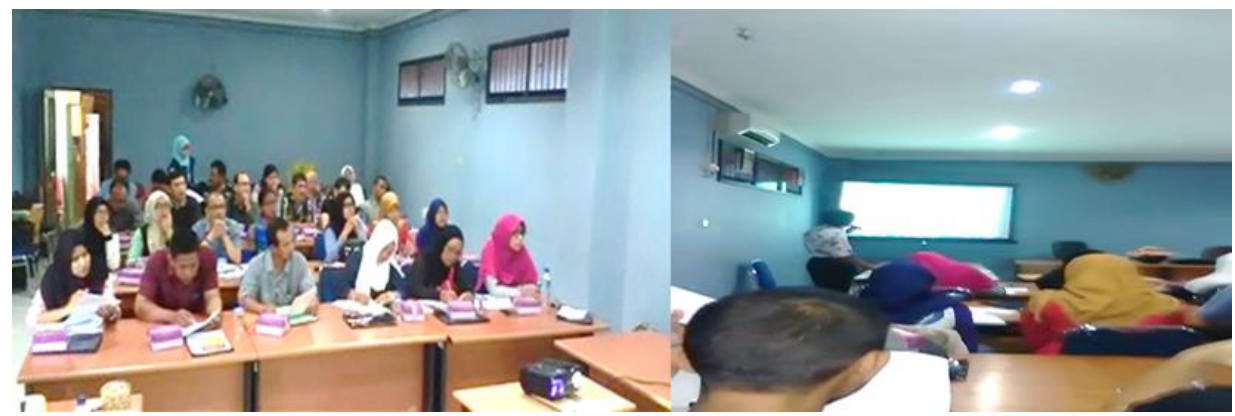

Gambar 9. Kegiatan penyuluhan keamanan pangan yang diikuti mitra sebagai salah satu syarat Penerbitan P-IRT

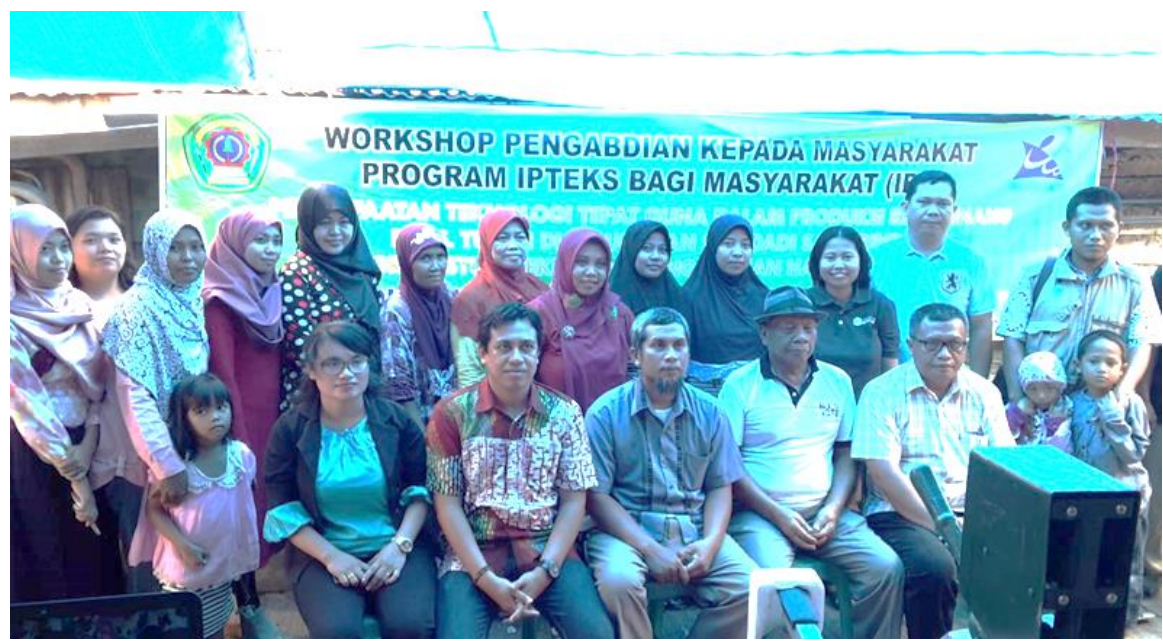

Gambar10. Kegiatan penyuluhan dan Pelatihan

Selain dari keempat item diatas, kegiatan edukasi dan pendampingan bagi mitra juga kami lakukan. Kegiatan pendampingan dan pembinaan terhadap pengolahan rengginang dengan melakukan worskshop ditempat Mitra dengan mengundang masyarakat disekitar rumah Mitra. Dalam hal ini kami juga mengundang beberapa staf dosen Program Studi Teknologi Pengolahan Hasil Perkebunan Politeknik Pertanian Negeri Samarinda untuk memberikan bimbingan terhadap produk pangan. Hal ini dilakukan supaya masyarakat mendapat ilmu yang baik dalam penangan bahan pangan yang baik.

\section{KESIMPULAN}

Kegiatan iptek bagi masyarakat ini dapat disimpulkan bahwa (1) Penggunaan alat pencetak rengginang dapat meningkatkan kepadatan serta 
kualitas dari rengginang tersebut. Selain itu, pelaku usaha tersebut (Mitra) dapat bekerja cepat dari biasanya, (2) Produksi Rengginang dapat dilakukan setiap hari tanpa ada rasa cemas dan takut, karena tidak tergantung cuaca (matahari). Dengan adanya alat pengering ini dapat meningkatkan jumlah produksi rengginang yang pada awalnya sekitar 25 kilo dalam 2 hari menjadi $30-50 \mathrm{~kg}$ perhari, (3) Penggunaan kemasan yang baik dan label yang menarik juga dapat meningkatkan pendapatan ekonomi Mitra, karena konsumen lebih suka membeli yang dikemas dengan baik daripada hanya dikemas dengan kresek biasa.

Dari hasil kegiatan pengabdian ini banyak memberikan efek positif bagi mitra dan para pengusaha rengginang lainnya bahwa betapa pentingnya penggunaan teknologi tepat guna dan perlunya legalitas usaha untuk menjamin keamanan pangan bagi konsumen, dan diharapkan bahwa kegiatan seperti ini akan terus berlanjut sebagai usaha untuk memberikan pembinaan dan pendampingan bagi usaha mikro yang memiliki prospek agar bisa survive dan berkembang kemasa yang akan datang.

\section{UCAPAN TERIMAKASIH}

Kami mengucapkan terimkasih sebesar-besarnya Kepada Kementerian Riset, Teknologi dan Pendidikan Tinggi Direktorat Pengelolaan Kekayaan Intelektual, yang telah memberikan kepercayaan dan mendanai Kegiatan pengabdian masyarakat ini.

\section{DAFTAR RUJUKAN}

Kartasapoetra. A.G.1989. Teknologi Penanganan Pasca Panen. Penerbit Bina Aksara, Jakarta.

Naibaho, NM., Syahrumsyah, H., dan Suprapto, H.2009. Studi waktu dan metode blancing terhadap sifat fisiko-kimia tepung talas Belitung (Xanthosoma Sagittifolium). Jurnal Teknologi Pertanian, Volume 4, Universitas Mulawarman.

Naibaho, NM., Saragih, B., dan Rudito. 2018. Pengantar Teknologi Pangan (Manajemen Pengolahan Krupuk Amplang). Penerbit Wade publish, Kediri.

Margono, T. dkk., 1993. Buku Panduan Teknologi Pangan. Pusat Informasi Wanita dalam Pembangunan PDII-LIPI, Jakarta.

Made Astawan Dan Mita Wahyuni Astawan, 1991" Teknologi Pengolahan Pangan Nabati Tepat Guna" Akademika Prassindo. Jakarta.

Mulyanah E dan Hellyana, CM., 2015. Perancangan Dan Pembuatan Alat Pengering Kerupuk Otomatis Menggunakan Mikrokontroler atmega16. Jurnal Evolusi - Volume 3 No 2.

Wijoyo., Nurhidayat, A., Sugiyanto. 2010, Rekayasa Alat Pengering Untuk Meningkatkan Produktifitas UKM Emping Mlinjo. Prosiding Seminar Nasional Sains dan Teknologi. Semarang. 